\title{
Racial and ethnic differences in the students' readiness, identity, perceptions of institutional diversity, and desire to join the environmental workforce
}

\author{
Dorceta E. Taylor ${ }^{1}$
}

Published online: 7 October 2017

(C) The Author(s) 2017. This article is an open access publication

\begin{abstract}
There is strong evidence that minority students are interested in environmental careers despite data showing that the percentage of people of color currently employed in environmental organizations is low. This study explores this conundrum by examining five factors that are related to workforce diversity. It assesses the racial and ethnic differences in (a) academic preparation for environmental work, (b) environmental identity, (c) the extent to which students are interested in pursuing careers in the environmental field, (d) the factors that influence students when deciding whether to accept environmental jobs, and (e) students' salary expectations. This study analyzes data from 157 students-46 Whites, 43 Blacks, and 68 other racial minorities. Data was collected from students participating in science, technology, engineering, and math programs hosted by at a large public university, a mid-sized private university, and a historically Black university. The data, collected from May to June 2016, revealed that minority and White students have similar grades, are taking a similar range of courses, and are members of campus environmental clubs. Students were more likely to describe themselves as an environmentalist rather than as a conservationist. The study also found that minority students are most comfortable working in organizations that promise jobs with upward mobility, leadership opportunities, and incorporate diversity activities in their programming. Though minority students tended to have salary expectations that were higher than that of White students, the differences were insignificant. Moreover, the mean salary that students would accept to work
\end{abstract}

Dorceta E. Taylor

dorceta@umich.edu

1 School for Environment and Sustainability, University of Michigan, Ann Arbor, MI, USA in environmental organizations is compatible with what is currently being paid in the field.

Keywords Black · White · Minority · Salary · Conservation · Jobs · Gender · Race · Graduate $\cdot$ Undergraduate $\cdot$ Academic

\section{Introduction}

When President Kennedy took office in 1961, high on his agenda was the issue of federal workforce diversity. This prompted Stuart Udall, then secretary of the Department of the Interior, to ask how many Blacks were employed in the National Park Service. When he found out that there was only one Black park ranger, Udall said "so what I will do is pull together in my immediate office a cadre of recruiters to go into places where Interior has never gone before, at least on a large scale, to recruit from the historically Black colleges and universities (p. 7)." That recruitment effort yielded Robert Stanton, a Black student at Hutson-Tillotson College, who borrowed money from his family so he could travel to Wyoming for his internship. Stanton later became the director of the National Park Service (McDonnell 2006).

In 2015 when Rhea Suh, a Korean-American woman, became president of the Natural Resources Defense Council, she vaulted into rarefied air as being only one of a handful of women at the helm of one of the ten most powerful environmental organizations (NRDC 2014). Not since Stanton's appointment to the directorship of the National Park Service has a person of color penetrated so far into the inner sanctum of environmental leadership. But what does this mean? Is this a harbinger of things to come?

Since the 1960s, numerous diversity programs aimed at increasing minority participation in environmental and related Science, Technology, Engineering, and Math (STEM) fields 
have been developed. Some environmental organizations and professional associations like the Ecological Society of America, the Society for Conservation Biology, and the Association for the Sciences of Limnology and Oceanography have active diversity committees and programs. Yet, highprofile top-level appointments of people of color such as Suh's and that of Aaron Mair, the first African American to become the President of the Sierra Club's board of directors, are still few and far between (Valtlin 2015).

This paper explores the potential for minorities to participate in the environmental labor force by examining five factors related to workforce diversity. It assesses the racial and ethnic differences in students' (a) academic preparation for environmental work, (b) environmental identity, (c) interest in pursuing careers in the environmental field, (d) decision-making related to whether accept environmental jobs, and (e) salary expectations.

This study is important because despite the rise of diversity programming, the percentage of minorities hired in mainstream environmental organizations as well as in some federal agencies is still low. It is appropriate to study students because they are an important part of the pipeline that brings new workers into the field. Yet we know little about how students think about the environmental workforce. Though diversity programs target minority students, there is a paucity of data that provide information on how such students feel about embarking on careers in the environmental workforce, what factors will be important in their decision to work in environmental organizations, and what they want from their experiences in the environmental workforce if they enter it. This study examines these important, but oft overlooked, elements of diversity and workforce dynamics.

\section{Gender diversity in environmental institutions}

In general, gender and racial diversity has increased in the environmental workforce over the last quarter century. As Table 1 shows, when Snow (1992) collected data on gender and leadership in environmental organizations in 1988, only $21 \%$ of the 265 top leaders (presidents, executive directors, and chief executive officers) of the institutions studied were female. Women were scarce among the membership of leading professional associations also. Hence in 1992, only $25 \%$ of the members of the Ecological Society of America were female (Holland et al. 1992). Data collected in 16 southeastern states plus the US Virgin Islands showed that $19.4 \%$ of the 12,245 natural resources professionals surveyed were females (Adams and Moreno 1998). However, data collected from multiple sources in 2006 shows that females typically comprised more than $30 \%$ of the staff of federal agencies (for the purposes of this study, the terms "federal agency" or "government agency" refer to federal agencies, bureaus, or departments that focus solely or primarily on environmental affairs). Females comprise $50.5 \%$ of the staff in mainstream environmental organizations (Partnership for Public Service 2007; Taylor 2008).

More recent studies show that the percentage of females working in environmental institutions continues to rise. Taylor (2014a, 2015) reports that in 2014, roughly $40 \%$ of the staff of government agencies and $56 \%$ of the staff in environmental nonprofits are female. Data collected on the staff of several federal land management agencies in 2015 show that the percentage of female employees ranged from $32 \%$ in the National Oceanic and Atmospheric Administration to $58.4 \%$ in the Farm Service Agency. In all but two bureaus (the Bureau of Reclamation and Reclamation and Enforcement), the percentage of female workers was higher in 2015 than it was in 2006 (Partnership for Public Service 2016, 2007). In 2016, the percentage of female workers in the energy sector ranged from $24 \%$ in energy efficiency to $34 \%$ among bioenergy/biomass generation staff (Department of Energy 2017). However, women are not evenly distributed throughout the hierarchy of the organizations in which they work. Table 2 shows that as seniority increases, the percentage of females in particular staff positions decreases. The table also shows that at all levels of staffing, the percentage of females in six different types of environmental organizations outpaces the percentage of minorities who are on staff.

\section{Racial diversity in environmental institutions}

The overall percentage of minorities has also increased in these institutions but not to the same extent as it has for females (Tables 1, 2, and 3). Early indicator studies found miniscule levels of minorities in environmental institutions. For example, an informal poll conducted by the New York Times (1990) found that minorities accounted for $1.9 \%$ of 745 staff of the largest environmental organizations. The percentage of minorities on the staff of environmental nonprofits has risen but has not exceeded 16\%. Stanton (2002) studied 6346 staff in 61 conservation organizations and found that minorities constituted $11 \%$ of the staff. Three years later, he reported that minorities comprised 14\% of the 4037 staff analyzed (Stanton 2005). Studies conducted by Taylor (2008, 2014a, 2015) found that minorities made up $14.6 \%$ of the staff of 166 environmental nonprofits in 2006, and $12 \%$ of the staff of organizations examined in 2014.

Minority membership in professional associations is growing, but remains low. In 1992, the Ecological Society of America reported that $4.1 \%$ of its members were minorities (Holland et al. 1992). Though the percentage has more than doubled, in 2010 , the society reported that $9 \%$ of its members were minorities (Beck et al. 2015).

Increasing numbers of minorities are working in government agencies. Adams and Moreno (1998) found that in 1993 minorities constituted $8.4 \%$ of the staff of natural resources agencies. Analysis of the workforce of federal land 


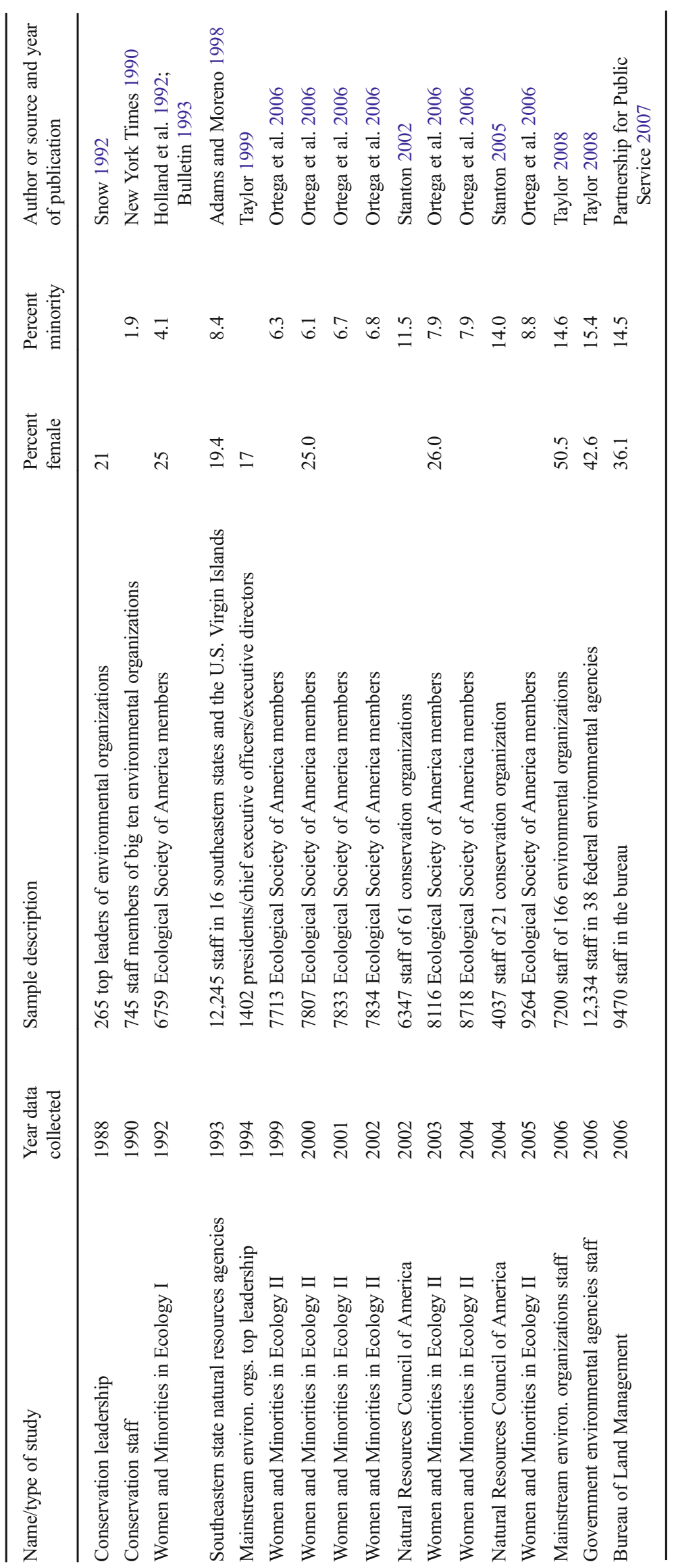




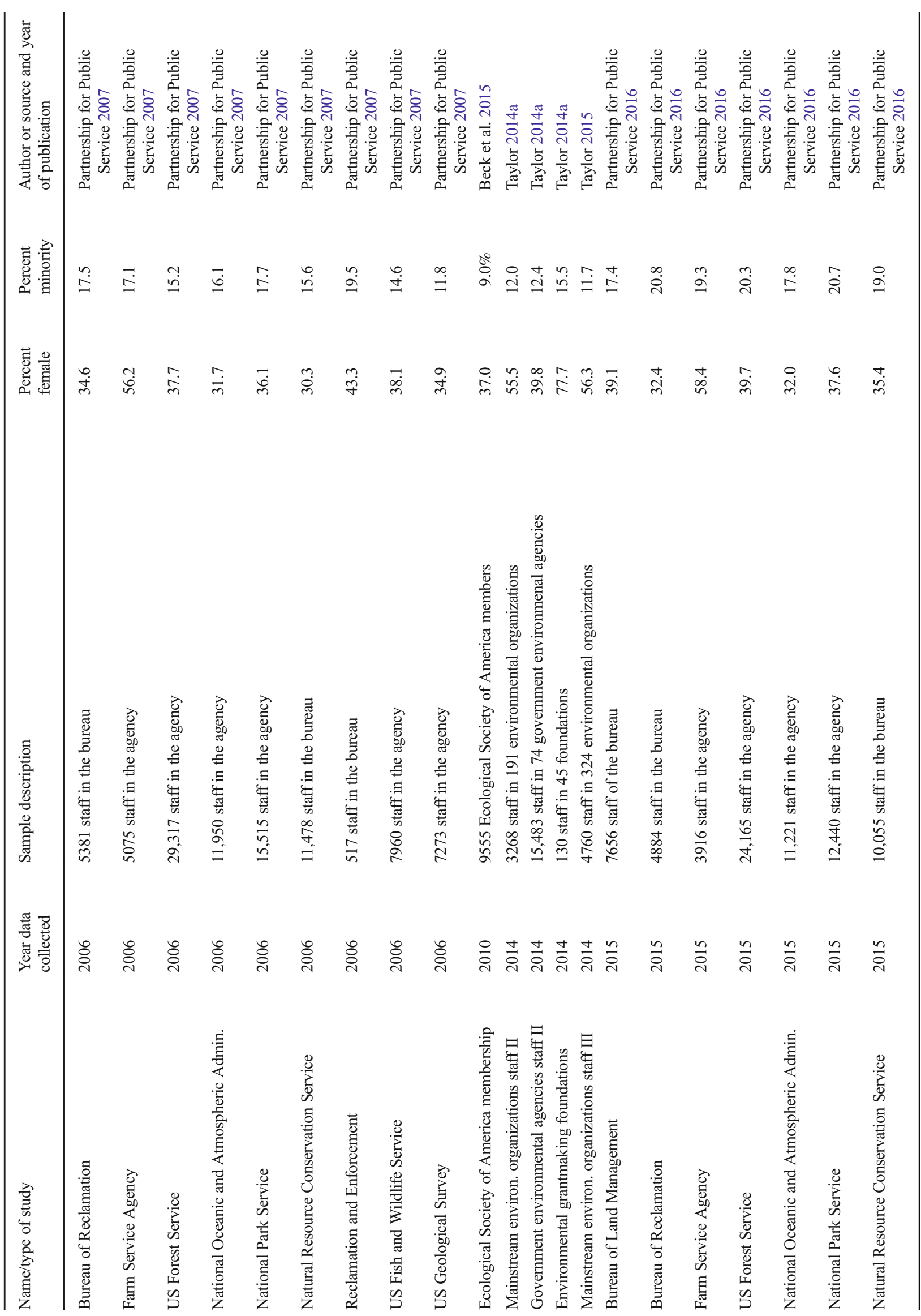




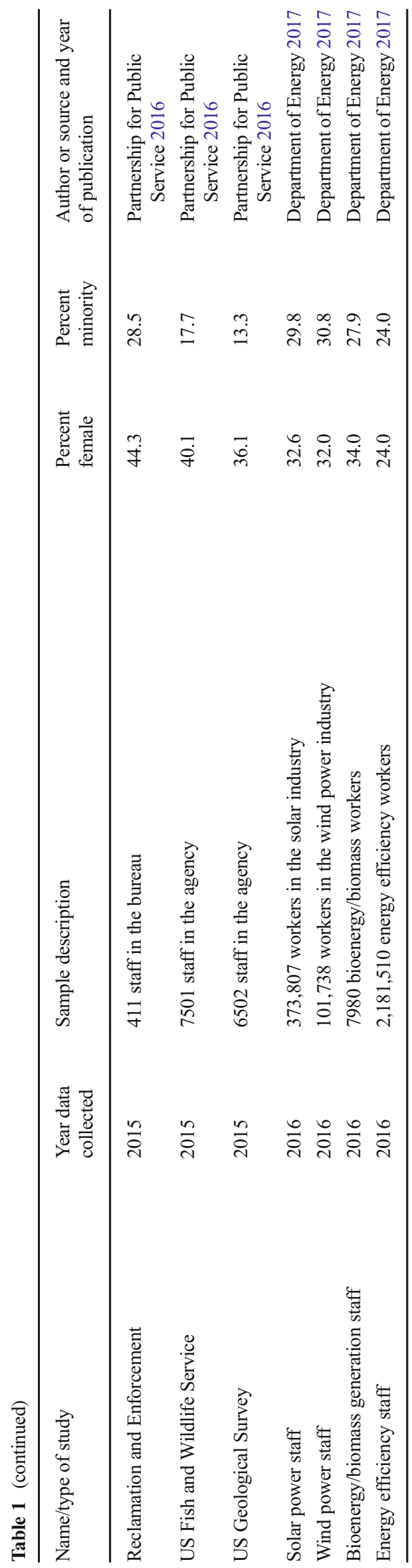

management agencies found that in 2006 the percentage of minorities on the staff was less than $20 \%$ in all the agencies studied. By 2015, the percentage of minorities on the staff of the ten agencies studied had increased such that $28.5 \%$ of the staff of Reclamation and Enforcement, $20.8 \%$ of those in the Bureau of Reclamation, $20.7 \%$ of the National Park Service staff, and $20.3 \%$ of the staff of the US Forest Service were minorities (Partnership for Public Service 2016, 2007). Minorities fare better in the energy sector where $30.8 \%$ of the wind power employees, $29.8 \%$ of those in solar power, $27.9 \%$ of the bioenergy/biomass workers, and $24 \%$ of the laborers in energy efficiency are minorities.

As Table 1 shows, despite across-the-board increases, minorities are still underrepresented in professional associations, mainstream environmental organizations, and government agencies. One can argue that minorities are underrepresented in these organizations because the US Census Bureau reports that ethnic minorities constituted $38.3 \%$ of the population in 2016 (U.S. Census Bureau 2016). Hence, their percentage in the aforementioned segments of the environmental workforce is much lower than their percentage in the population. Minority underrepresentation in environmental institutions is even more apparent as one moves up the organizational hierarchy (see Table 3). That is, the percentage of minorities in senior staff positions in environmental organizations is lower than the percentage who are in general staff positions (Taylor 2008, 2014a, 2015). This trend is more troubling when one examines the internship pipeline and new staff hires. This raises the question, are there enough minorities entering the workforce to increase the levels of racial diversity in these organizations? In 2014, minorities accounted for only $22.5 \%$ of the interns that 191 organizations hosted (Taylor 2014a). When a larger sample of environmental organizations was analyzed, minorities comprised $20.9 \%$ of the interns hosted in 324 institutions. In addition, $14 \%$ of the staff hired in 3 years prior to the survey were minorities (Taylor 2015). Because the percentages of minorities serving as interns or who are being hired in environmental organizations are low, it is important for us to understand the extent to which minorities are interested in working in environmental organizations and what factors influence their decisions to do so.

\section{The role of students}

Students play a critical role in diversity efforts as they are future scholars, faculty, research scientists, members of professional associations, staff in environmental organizations, board members, and policymakers. This leads some to argue that the environmental field lacks racial diversity because minority students are not interested in the environment, they do not have the requisite backgrounds in STEM disciplines, there is not a robust pipeline of 


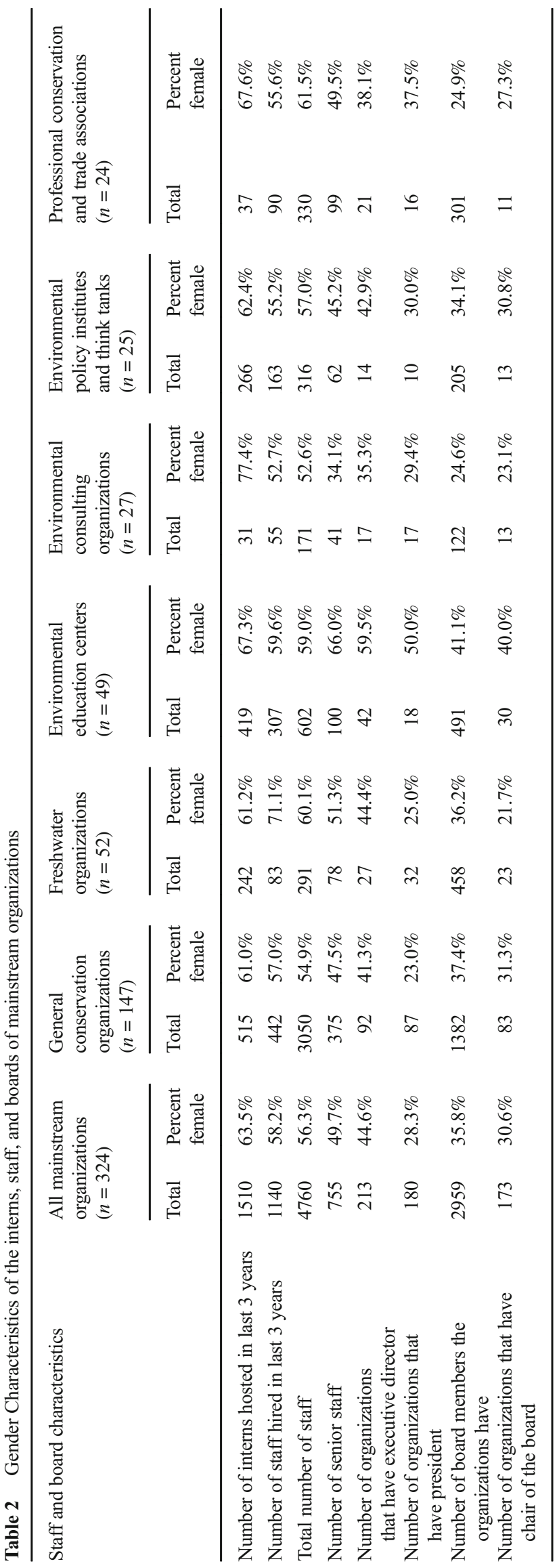

minority students to incorporate into the environmental workforce, minority students do not want environmental jobs, and that minority students desire wages that are too high for organizations to pay (Taylor 2007, 2014a).

Those espousing the lack-of-interest and lack-of-academicpreparation arguments point to earned degrees in relevant STEM fields that show that in 2013 minority students earned $13 \%$ of the bachelor's degrees, $11.2 \%$ of master's degrees, and $9.7 \%$ of the doctorates in agriculture and natural resources. They also earned $32.9 \%$ of the bachelor's degrees, $25.6 \%$ of master's degrees, and $18.5 \%$ of the doctorates in the biological and biomedical sciences (Snyder and Dillow 2015). Though National Science Foundation (NSF) data show that these percentages have increased steadily since 1993, they are particularly low in natural resources and agriculture especially when advanced degrees are considered (National Science Foundation 2015). Advanced degrees are required or preferred for many environmental jobs.

\section{Minority students and the desire for environmental careers}

There is ample evidence that minority students are interested in pursuing environmental careers. An Environmental Careers Organization study documented minority students' enthusiasm for working in environmental science as early as 1992 . That year, $65 \%$ of the minority students surveyed said they wanted to work in a grassroots environmental organizations and 59\% would like to work in a national environmental organization (Environmental Careers Organization 1992). Minority students have also been participating in the Ecological Society of America's Strategies for Ecology Education, Diversity, and Sustainability (SEEDS) program since its inception in 1995 (Ecological Society of America 2003). Similarly, the American Institute of Biological Sciences instituted diversity programming in 2001 (AIBS 2016). In response to a report issued by the Association of Zoos and Aquariums in 2004 that pointed to the lack of racial diversity in the zoo and aquarium workforce, the Wildlife Conservation Society developed Bridging the Gap. The mentorship program exposes minority high school students to conservation experiences and careers. An evaluation of the program found that $82 \%$ of the program participants surveyed reported that they planned to pursue STEM careers (Wildlife Conservation Society 2015).

Programs such as these are in demand from minority students. For instance, the Doris Duke Conservation Scholars Program (DDCSP) at the University of Michigan - a diversity program housed in the School for Environment and Sustainability (SEAS) - generated a large applicant pool in which minority students were well represented (DDCSP 2016). In 2016, several hundred undergraduates in STEM fields began the application and 164 completed the application 


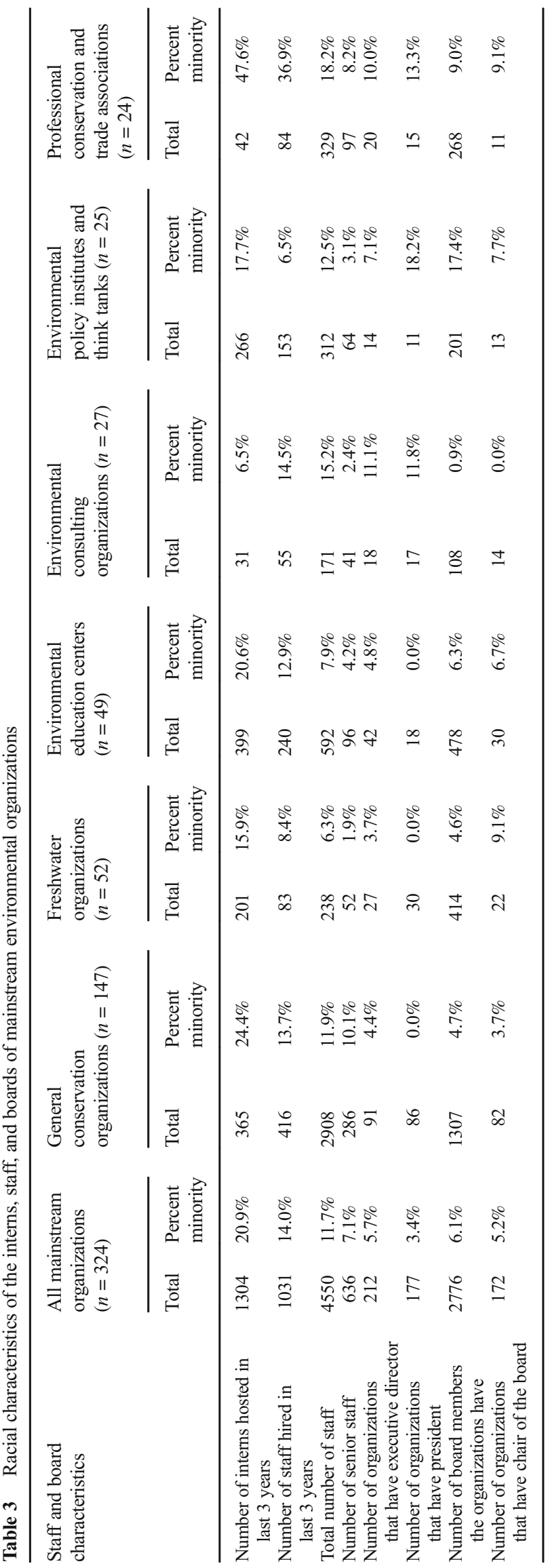

for 20 2-year summer internships that were hosted at SEAS. Half of the applicants were minority students. The results are similar for the 2017 application cycle.

Similar results have been found elsewhere. Doris Duke Conservation Scholars programs housed at the University of Washington, Northern Arizona University, University of California at Santa Cruz, and the University of Florida also report strong interest from minority students (Doris Duke Charitable Foundation 2016). The Organization for Tropical Studies at Duke University, which administered NSFsponsored Research Experience for Undergraduates (REU) field biology courses in Costa Rica from 2005 to 2016, also had robust applicant pools. During its operation, the program expanded the number of students admitted and broadened its focus; it went from serving only Native American and Pacific Islander students to one that served Black and Hispanic students as well (Organization for Tropical Studies 2016).

Graduate environmental fellowships such as the Environmental Fellows Program which arose from a collaboration between SEAS, the Environmental Grantmakers Association, and the C. S. Mott Foundation also attract large numbers of minority applicants (Leon and Taylor 2016; see also https://efp-umich.squarespace.com/). In 2016, the first year of operation, the program had 104 applications for 17 fellowship slots. Most of the applicants were minorities. The applicant pool was similar in 2017. Long-running programs like NSF's Louis Stokes Alliance Minority Programs (LSAMP) also continue to attract minority applicants (Clewell et al. 2005).

\section{Study methodology and sample characteristics}

This study used a purposive sampling technique to identify and survey students who participated in or sought to participate in STEM programs hosted by a large, public, Midwestern university; a medium-sized, private mid-Atlantic university; and a small, private, historically Black university in the Deep South. Contact information was obtained for students seeking to participate in programs organized by these universities. The students completed all or part of Web applications for summer internships, summer science courses, or to attend a conference. Applications came from students attending colleges and universities from around the country. Surveys were sent to 391 students for whom contact information was available between May 4, 2016, and June 21, 2016. The surveys, administered through a Qualtrics platform, allowed for anonymity. The platform also prevented an individual from responding to the survey more than once. Usable surveys were received from 161 students. The effective response rate was $41.2 \%$.

Responses were obtained from students who were admitted into summer internship programs as well as from those who were not. Consequently, the sample had students whose 
interests in the environment and exposure to environmental coursework ranged from minimal to substantial.

Four students refrained from identifying their racial background; hence, 157 responses will be analyzed for this paper. This sample consists of $46(29.3 \%)$ White students, 43 $(27.4 \%)$ Black students, and $68(43.3 \%)$ other racial and ethnic minority students. The category "other minority students" consists of students who are of Native American, Pacific Islander, Hispanic or Latino/a, Asian, and Arab/Middle Eastern heritage. The sample size for each of these groups was too small to analyze independently so they are combined.

The sample contains both undergraduates and graduate students. One hundred and sixteen or $73.9 \%$ of the sample are undergraduates. The remaining 41 or $26.1 \%$ are graduate students. Respondents range in age from 18 to 46 years of age. Study participants specialize in a variety of subject areas. All but one respondent reported on their major: $44 \%$ are environmental science/environmental studies/environmental policy majors, 24\% major in biology/ecology, 6\% in engineering, and the remaining $26 \%$ in agriculture, general studies, communication, computer science, history, urban planning, sociology, American studies, political science, social work, architecture, biotechnology, nursing, dentistry, geography, global studies, landscape architecture, English, math, forestry, public health, psychology, East Asian studies, environmental education, higher education administration, and operations technology management.

\section{Results}

\section{Academic preparation}

Students of color are often perceived as lacking the educational background necessary for work in environmental organizations. As data presented above show, they are underrepresented among interns hosted by environmental organizations and among the new hires that are made. However, minority students in this sample have comparable grade point averages (GPA) to White students. The mean GPA for the sample is 3.48. The mean GPA for White respondents is 3.51; it is 3.44 for Black students and 3.49 for other minorities. These differences are not significant $(p=0.725)$.

Respondents indicated whether they had taken courses in 24 subject areas. These are courses that are relevant to the environmental field and provide academic preparation for the environmental workforce. Contrary to the widely-held view that minority students are not academically prepared to work in environmental organizations, Table 4 shows that the minority students in the sample are taking a similar suite of coursework to White students. Despite some variations (such as a higher percentage of students of color taking biology courses than White students or White students being more likely to have taken environmental science, environmental studies, and sustainability courses than students of color), one cannot argue that the coursework of students of color is so drastically different from that of White students that it renders students of color ineligible for work in environmental organizations. The five most popular courses are biology, environmental sciences, ecology/ecosystems studies, environmental studies, and environmental justice. The respondents reported that they plan to continue taking more courses like those listed in Table 4 in the future.

Study participants were also involved in extracurricular environmental activities. Roughly $56 \%$ of the sample were members of student environmental clubs; $65.2 \%$ of Whites, $53.5 \%$ of Blacks, and $51.5 \%$ of other minority students were members of student environmental clubs.

\section{Racial and ethnic differences in environmental identity}

The students were asked to say how they identified themselves. They were given four identities (scientist, environmentalist, conservationist, and environmental justice practitioner) and asked to rank each on a Likert scale that ranged from 1 to 5. The rankings were as follows: $1=$ never, $2=$ sometimes, 3 = about half the time, $4=$ most of the time, and $5=$ always. Definitions of the identities were not provided to participants; hence, their rankings were based on their perceptions of how they thought about themselves. Overall, students indicated that the environmentalist identity was most salient and the scientist least salient to them (Table 5).

Overall, $72.7 \%$ of the students identified themselves most of the time or always as an environmentalist while $60.4 \%$ identified most of the time or always as a conservationist. For some students, the environmental identity is not a standalone professional descriptor; it is intertwined with their identities as conservationists, environmental justice practitioners, and scientists. Of the students who said they always identified themselves as an environmentalist, $82.7 \%$ also always identified themselves as a conservationist. This is particularly true of Black students - $92.9 \%$ of those who always think of themselves as an environmentalist also always think of themselves as conservationists; $80 \%$ of other minority students and $77.8 \%$ of White students who always think of themselves as environmentalists also always think of themselves as conservationists. Hence, the environmentalist and conservationist identities overlap for some students. The environmentalist and environmental justice identities also overlap. The study found that $68.9 \%$ of the students who always thought of themselves as an environmentalist also always thought of themselves as an environmental justice practitioner. The overlap is less noticeable between the conservation and environmental justice identities. Just over half $(51.1 \%)$ of the respondents who always thought of themselves as conservationists also always thought of themselves as environmental justice practitioners. 
Table 4 Racial differences in the relevant academic coursework completed

\begin{tabular}{|c|c|c|c|c|}
\hline \multirow[t]{2}{*}{ Courses } & \multicolumn{4}{|c|}{ Percent taking one or more courses } \\
\hline & Total sample & White & Black & Other minorities \\
\hline Biology & 74.8 & 73.9 & 79.1 & 72.7 \\
\hline Environmental sciences & 47.7 & 61.4 & 44.2 & 45.5 \\
\hline Ecology/ecosystems studies & 44.8 & 55.6 & 32.6 & 45.5 \\
\hline Environmental studies & 36.8 & 50.0 & 34.9 & 28.8 \\
\hline Environmental justice & 31.0 & 28.3 & 34.9 & 30.3 \\
\hline Conservation & 29.9 & 40.0 & 18.6 & 30.3 \\
\hline Geology/earth sciences & 29.7 & 37.0 & 25.6 & 27.3 \\
\hline Climate sciences & 26.0 & 35.6 & 23.7 & 21.2 \\
\hline Sustainability & 25.8 & 41.3 & 16.3 & 21.2 \\
\hline Natural resources management & 22.6 & 23.9 & 30.2 & 16.7 \\
\hline Geography & 20.6 & 19.6 & 27.9 & 16.7 \\
\hline Agriculture/agronomy & 19.4 & 23.9 & 20.9 & 15.2 \\
\hline Botany & 18.7 & 17.4 & 23.3 & 16.7 \\
\hline Marine/ocean sciences & 17.5 & 19.6 & 20.9 & 13.8 \\
\hline Nature writing/environmental literature & 16.1 & 19.6 & 16.3 & 13.6 \\
\hline Biochemistry & 15.6 & 15.6 & 14.0 & 16.7 \\
\hline Atmospheric sciences & 15.5 & 17.4 & 16.3 & 13.6 \\
\hline Water resources/hydrology & 12.9 & 17.4 & 14.0 & 12.1 \\
\hline Soil sciences & 12.3 & 19.6 & 14.0 & 6.1 \\
\hline Natural history & 10.3 & 13.0 & 9.3 & 9.1 \\
\hline Wildlife management & 10.3 & 13.0 & 11.6 & 7.6 \\
\hline Zoology & 9.7 & 13.0 & 2.3 & 12.1 \\
\hline Forestry & 9.1 & 8.7 & 7.1 & 10.6 \\
\hline Horticulture & 4.5 & 0.0 & 9.3 & 4.5 \\
\hline
\end{tabular}

The least overlap was observed between the scientist identity and other identities. Only $42.5 \%$ of the sample saw themselves as a scientist most of the time or always. The study found that $43.1 \%$ of the respondents who always think of themselves as scientists also always think of themselves as conservationists. There was even less overlap between the scientist and environmentalist identities: that is, $35.7 \%$ of the respondents who always think of themselves as scientists also always think of themselves as environmentalists. The lowest level of overlap was observed between the scientist and environmental justice identities - $31.8 \%$ of those who always thought of themselves as scientists also always think of themselves as environmental justice practitioners.

However, students' desire to label themselves either as an environmentalist or conservationist seem to diminish with length of time in school. While the mean for the undergraduates identifying themselves as environmentalists was 4.12 , it was 3.51 for graduate students. Similar declines were noticed for the conservationist identity; the mean was 3.66 for undergraduates and 3.39 for graduate students who said they identified themselves as conservationists. To the contrary, graduate students were more likely to identify themselves as environmental justice practitioners than undergraduates - the mean for graduate students was 3.46 while it was 3.35 for undergraduates.

There were differences between the way men and women identified themselves, but these were not significant. Males were more likely to identify themselves as scientists than females; the male mean was 3.38 while the female mean was 2.89. Males were also more likely to think of themselves as environmentalists than females. The mean for males was 4.26 while it was 3.87 for females. Similarly, the conservationist identity was more likely to be embraced by males than females - the means were 3.85 and 3.53 , respectively. When it came to the environmental justice identity, the pattern held. The mean for males was higher than it was for females; the respective means were 3.56 and 3.31 .

\section{Desire to work in environmental organizations}

Respondents also expressed enthusiasm for working in various sectors of the environmental field upon graduation. They were asked to indicate how interested they were in working for 14 different types of environmental organizations. 
Table 5 Racial differences among students identifying with a given professional identity

\begin{tabular}{|c|c|c|c|c|c|}
\hline \multirow[t]{2}{*}{ Race or ethnicity } & \multirow[t]{2}{*}{$n$} & \multirow[t]{2}{*}{ Mean $(\bar{x})$} & \multicolumn{3}{|l|}{ Percent } \\
\hline & & & Never & $\begin{array}{l}\text { Sometimes/about } \\
\text { half the time }\end{array}$ & $\begin{array}{l}\text { Most of the } \\
\text { time/always }\end{array}$ \\
\hline \multicolumn{6}{|l|}{$\begin{array}{l}\text { I identify myself as } \\
\text { a scientist: }\end{array}$} \\
\hline Total sample & 154 & 2.97 & 25.3 & 31.8 & 42.9 \\
\hline White & 46 & 2.89 & 28.3 & 34.8 & 37.0 \\
\hline Black & 42 & 3.02 & 26.2 & 23.8 & 50.0 \\
\hline Other minorities & 66 & 2.98 & 22.7 & 34.8 & 42.5 \\
\hline \multicolumn{6}{|c|}{$\begin{array}{l}\text { I identify myself as an } \\
\text { environmentalist: }\end{array}$} \\
\hline Total sample & 154 & 3.95 & 5.2 & 22.1 & 72.7 \\
\hline White & 46 & 4.02 & 6.5 & 15.2 & 78.3 \\
\hline Black & 43 & 3.98 & 4.7 & 20.9 & 74.4 \\
\hline Other minorities & 65 & 3.89 & 4.6 & 27.7 & 67.7 \\
\hline \multicolumn{6}{|l|}{$\begin{array}{l}\text { I identify myself as a } \\
\text { conservationist: }\end{array}$} \\
\hline Total sample & 155 & 3.59 & 11.6 & 27.8 & 60.6 \\
\hline White & 46 & 3.85 & 6.5 & 26.1 & 67.4 \\
\hline Black & 43 & 3.30 & 14.0 & 37.3 & 48.9 \\
\hline Other minorities & 66 & 3.59 & 13.6 & 22.8 & 63.6 \\
\hline \multicolumn{6}{|c|}{$\begin{array}{l}\text { I identify myself as an } \\
\text { environmental justice } \\
\text { practitioner: }\end{array}$} \\
\hline Total sample & 155 & 3.38 & 11.0 & 38.1 & 51.0 \\
\hline White & 46 & 3.11 & 8.7 & 47.8 & 43.5 \\
\hline Black & 43 & 3.74 & 9.3 & 30.3 & 60.5 \\
\hline Other minorities & 66 & 3.33 & 13.6 & 36.4 & 50.0 \\
\hline
\end{tabular}

Students rated interest in working in each type of organization on a five-point Likert scale. The scale was as follows: 1 = very disinterested, 2 = somewhat disinterested, 3 = neither interested or disinterested, $4=$ somewhat interested, and $5=$ very interested. Students had the strongest preference for working in federal agencies; $81.7 \%$ were somewhat or very interested in working in such organizations $(\bar{x}=4.18)$. More than three quarters of the students were also somewhat or very interested in working for state departments of natural resources $(\bar{x}$ $=4.06)$, environmental think tanks $(\bar{x}=4.07)$, and in academic institutions $(\bar{x}=4.05)$. Students were least interested in working in zoos or aquariums, museums focusing on environmental or natural history, botanical gardens or arboretums, and parks (see Table 6).

The top choices of workplaces for White students are federal agencies, state departments of natural resources, environmental nonprofits, and conservation professional associations. More than $80 \%$ of White students wanted to work in these organizations. Black students were most likely to say they wanted to work in federal agencies, state departments of natural resources, academic institutions, and environmental think tanks; roughly three quarters of them wanted to work in these organizations. While the top workplace choice for other minority students were federal agencies, a high percentage of these students also wanted to work in environmental think tanks, professional conservation associations, and academic institutions-more than $78 \%$ desired work in these organizations.

The top choices for undergraduates were working in federal agencies $(\bar{x}=4.19$, academic institutions $(\bar{x}=4.11)$, and environmental nonprofits $(\bar{x}=4.09)$. For graduate students, the most desired places to work were in environmental think tanks $(\bar{x}=4.20)$, federal agencies $(\bar{x}=4.15)$, and environmental justice organizations $(\bar{x}=4.00)$.

The top five choices for women were working in the following: a federal agency $(\bar{x}=4.19)$, a state department of natural resources $(\bar{x}=4.12)$, an environmental policy think tank $(\bar{x}=4.08)$, an academic institution $(\bar{x}=4.01)$, and an environmental nonprofit $(\bar{x}=4.00)$. For men, the top five choices were working in the following: a federal agency $(\bar{x}$ $=4.35)$, an academic institution $(\bar{x}=4.24)$, an environmental nonprofit $(\bar{x}=4.09)$, an environmental policy think tank $(\bar{x}$ $=4.09)$, and state departments of natural resources $(\bar{x}=4.06)$. Women are least likely to want to work in museums of natural 
Table 6 Interest in working in environmental organizations upon graduation

\begin{tabular}{|c|c|c|c|c|c|c|c|c|}
\hline \multirow[t]{2}{*}{ Area of the environmental workforce } & \multicolumn{4}{|c|}{$\begin{array}{l}\text { Percent who are somewhat or very interested } \\
\text { in working in organizations }\end{array}$} & \multicolumn{4}{|c|}{ Mean score $($ range $=1-5)$} \\
\hline & $\begin{array}{l}\text { Total } \\
\text { sample }\end{array}$ & White & Black & $\begin{array}{l}\text { Other } \\
\text { minorities }\end{array}$ & $\begin{array}{l}\text { Total } \\
\text { sample }\end{array}$ & White & Black & $\begin{array}{l}\text { Other } \\
\text { minorities }\end{array}$ \\
\hline $\begin{array}{l}\text { Federal government environmental agency, } \\
\text { e.g., US Fish and Wildlife Service }\end{array}$ & 81.7 & 86.7 & 76.2 & 81.8 & 4.18 & 4.24 & 4.10 & 4.20 \\
\hline State departments of natural resources & 78.6 & 86.9 & 76.2 & 74.2 & 4.06 & 4.17 & 4.05 & 4.00 \\
\hline $\begin{array}{l}\text { Environmental think tank, e.g., Rocky } \\
\text { Mountain Institute, Env. Policy Institute }\end{array}$ & 77.9 & 76.1 & 73.9 & 81.8 & 4.07 & 4.04 & 4.05 & 4.11 \\
\hline Academic institution as research scientist, etc. & 77.3 & 76.1 & 76.2 & 78.8 & 4.05 & 4.07 & 4.07 & 4.02 \\
\hline $\begin{array}{l}\text { Environmental nonprofit, e.g., Audubon } \\
\text { Society, National Wildlife Federation }\end{array}$ & 74.5 & 82.6 & 68.3 & 72.8 & 3.97 & 4.17 & 3.83 & 3.92 \\
\hline $\begin{array}{l}\text { Professional conservation association, } \\
\text { e.g., Ecological Society of America }\end{array}$ & 73.4 & 80.4 & 54.7 & 80.3 & 3.94 & 4.13 & 3.62 & 4.02 \\
\hline $\begin{array}{l}\text { Environmental justice organization, } \\
\text { e.g., We Act }\end{array}$ & 65.6 & 54.3 & 71.4 & 69.7 & 3.87 & 3.72 & 4.00 & 3.89 \\
\hline Environmental education center & 64.5 & 69.2 & 63.4 & 63.1 & 3.64 & 3.64 & 3.68 & 3.62 \\
\hline Nature center & 63.7 & 74.1 & 57.1 & 60.6 & 3.75 & 3.91 & 3.62 & 3.71 \\
\hline $\begin{array}{l}\text { Environmental grantmaking foundation, } \\
\text { e.g., Alaska Conservation Foundation }\end{array}$ & 61.0 & 67.4 & 59.5 & 57.5 & 3.64 & 3.80 & 3.64 & 3.53 \\
\hline Parks & 55.2 & 65.2 & 50.0 & 51.6 & 3.49 & 3.65 & 3.33 & 3.47 \\
\hline Botanical garden or arboretum & 53.3 & 54.3 & 47.6 & 56.1 & 3.50 & 3.54 & 3.36 & 3.56 \\
\hline $\begin{array}{l}\text { Museum focusing on conservation or } \\
\text { natural history }\end{array}$ & 53.2 & 60.9 & 42.9 & 54.6 & 3.22 & 3.35 & 3.02 & 3.26 \\
\hline Zoo or aquarium & 50.7 & 58.7 & 38.0 & 53.0 & 3.24 & 3.54 & 2.83 & 3.29 \\
\hline
\end{tabular}

history $(\bar{x}=3.30)$ while men are least likely to say they want to work in zoos or aquariums $(\bar{x}=3.00)$.

\section{Factors influencing the decision to participate in the environmental workforce}

Despite their enthusiasm and preparation, if historical trends hold, most of the minority students in the sample will not end up being employed in the environmental workforce. Much more research should be conducted to fully understand why this may be the case. We do not understand this critical area of workforce dynamics very well because labor market studies tend to ask those currently employed in organizations - and not potential employees - to analyze why the percentages of minorities on their staff are low (Taylor 2014a). Hence, it is rare that researchers ask students to say what factors will influence their decisions to work in the environmental field (Taylor 2007).

The students in this study were asked to ponder this question. They were asked to say how 23 factors would influence their decision to work in environmental organizations upon graduation. They rated each factor on a Likert scale that ranged from 1 to 5 . On the scale $1=$ not at all important, 2 = somewhat unimportant, 3 = neither important nor unimportant, 4 = somewhat important, and 5 = very important.
As the mean comparisons in Table 7 show, by far the two most important factors for the whole sample were opportunities to take on leadership roles $(\bar{x}=4.73)$ and opportunities to be promoted $(\bar{x}=4.59)$. Black and other minority students found these factors to be more salient than White respondents. The importance of these two factors increases with time in school. Ergo, graduate students had higher means on both factors than undergraduates. For the factor, opportunities to grow and take on leadership roles, graduate students had a mean score of 4.93, while undergraduates garnered a mean score of 4.66. When it came to the factor, opportunities to be promoted, the graduate student mean was 4.73 , and undergraduate mean was 4.55 . These factors were more significant to men in their decision-making than women. Consequently, males had higher mean scores than females for opportunities to grow and take on leadership roles - males $(\bar{x}=4.85)$ and females $(\bar{x}=4.69)$ as well as for opportunities to be promoted-males $(\bar{x}=4.71)$ and females $(\bar{x}=4.56)$.

The presence of diversity programming in the organization $(\bar{x}=4.41)$, the cost of living in the place where the organization is located $(\bar{x}=4.23)$, and the racial diversity of the organization's leadership $(\bar{x}=4.22)$ are also among the five most important factors to students. In all instances, Black and other minority students ranked these factors higher than White students. These factors, as well as all the others examined, were also rated higher by graduate students than undergraduates. 
Table 7 Race and the importance of institutional factors in deciding on whether to work in environmental organizations

\begin{tabular}{|c|c|c|c|c|c|}
\hline \multirow[t]{2}{*}{ Organizational factors } & \multirow[t]{2}{*}{ Maximum score } & \multirow[t]{2}{*}{ Total sample mean } & \multicolumn{3}{|c|}{ Mean scores of each factor } \\
\hline & & & White & Black & Other minorities \\
\hline \multicolumn{6}{|l|}{ Single organizational factors } \\
\hline Opportunities to grow into and take on leadership positions & 5 & 4.73 & 4.70 & 4.91 & 4.64 \\
\hline Opportunities to be promoted & 5 & 4.59 & 4.35 & 4.79 & 4.62 \\
\hline The presence of diversity programming in the organization & 5 & 4.41 & 4.17 & 4.63 & 4.42 \\
\hline The cost of living in the place where the organization is located & 5 & 4.23 & 4.04 & 4.47 & 4.21 \\
\hline The racial diversity of the organization's leadership & 5 & 4.22 & 3.72 & 4.62 & 4.31 \\
\hline Availability of mentors for me in the organization & 5 & 4.21 & 4.20 & 4.28 & 4.17 \\
\hline The racial diversity of the organization's staff & 5 & 4.21 & 3.78 & 4.65 & 4.21 \\
\hline The organization does work in low-income communities & 5 & 4.20 & 3.80 & 4.38 & 4.36 \\
\hline The amount of salary being offered to me & 5 & 4.14 & 3.91 & 4.43 & 4.12 \\
\hline The racial diversity of the organization's membership & 5 & 4.12 & 3.67 & 4.54 & 4.17 \\
\hline The organization does work in communities of color & 5 & 4.11 & 3.56 & 4.44 & 4.27 \\
\hline The gender diversity of the organization's leadership & 5 & 4.07 & 3.80 & 4.43 & 4.03 \\
\hline Region of the country the organization is located in & 5 & 4.03 & 4.04 & 4.02 & 4.02 \\
\hline The class diversity of the organization's leadership & 5 & 4.01 & 3.83 & 4.07 & 4.11 \\
\hline The gender diversity of the staff & 5 & 4.01 & 3.76 & 4.47 & 3.88 \\
\hline The class diversity of the organization's staff & 5 & 3.97 & 3.80 & 4.12 & 4.00 \\
\hline The gender diversity of the organization's membership & 5 & 3.96 & 3.67 & 4.42 & 3.86 \\
\hline The class diversity in the organization's membership & 5 & 3.93 & 3.78 & 4.07 & 3.94 \\
\hline Urban or rural location & 5 & 3.91 & 3.80 & 4.07 & 3.88 \\
\hline The extent to which I was recruited by the organization & 5 & 3.82 & 3.63 & 3.79 & 3.97 \\
\hline The organization is located close to low-income communities & 5 & 3.76 & 3.48 & 3.88 & 3.88 \\
\hline The organization is located close to communities of color & 5 & 3.74 & 3.33 & 3.95 & 3.88 \\
\hline The organization reflects my cultural background & 5 & 3.48 & 2.89 & 3.64 & 3.79 \\
\hline \multicolumn{6}{|l|}{ Aggregate Organizational Factors } \\
\hline Leadership, promotion, and mentoring opportunities & 15 & 13.52 & 13.24 & 13.98 & 13.42 \\
\hline Racial diversity (of staff, leadership, and membership) & 15 & 12.38 & 11.17 & 13.49 & 12.50 \\
\hline Leadership diversity (gender, race, and class of leaders) & 15 & 12.14 & 11.35 & 12.81 & 12.26 \\
\hline Staff diversity (gender, race, and class of staff) & 15 & 12.14 & 11.26 & 13.14 & 12.09 \\
\hline Gender diversity (of staff, leadership, and membership) & 15 & 11.99 & 11.24 & 13.21 & 11.71 \\
\hline Membership diversity (gender, race, and class of members) & 15 & 11.93 & 11.13 & 12.90 & 11.86 \\
\hline Class diversity (of staff, leadership, and membership) & 15 & 11.84 & 11.33 & 12.26 & 11.92 \\
\hline $\begin{array}{l}\text { Organization's location (rural/urban, region, proximity to } \\
\text { communities of color, and low-income communities) }\end{array}$ & 20 & 15.41 & 14.57 & 15.93 & 15.65 \\
\hline Salary offer and cost of living & 10 & 8.35 & 7.96 & 8.79 & 8.33 \\
\hline $\begin{array}{l}\text { Where the organization does its work (communities of } \\
\text { color and low-income communities) }\end{array}$ & 10 & 8.26 & 7.28 & 8.72 & 8.64 \\
\hline Diversity programming and cultural background reflected & 10 & 7.88 & 7.07 & 8.26 & 8.21 \\
\hline
\end{tabular}

Male students were more concerned about the cost of living in the place where the job was located than female students. However, females expressed higher levels of concern about the racial diversity of the leadership in the organization and the presence of diversity programming in the institution offering the job than males.

There were significant racial differences on the question of cultural representation in environmental organizations. While the sample mean for the statement, "the organization reflects my cultural background" was 3.46; it was 2.89 for White students. Only $19.6 \%$ of White students thought it was somewhat or very important that the organizations they work in reflect their cultural background. In contrast, more than half of the students of color felt that it was somewhat or very important that their workplace should reflect their cultural background. White students were also much less likely than 
students of color to feel that it is somewhat or very important that organizations they are employed in do work in communities of color.

The more time respondents spend in school, the more salient diversity factors are to them. Graduate students had higher means than undergraduates for all but one of the diversity factors considered. In nine instances, graduate students had significantly higher means than undergraduates. The significant differences were evident for the following factors: the racial diversity of the staff of organizations, the salary being offered, urban or rural location of the organization, the region of the country the organization is located in, the availability of mentors in the organization, opportunities to grow and take on leadership roles, the extent to which the organization reflects the respondent's cultural background, whether the organization does work in communities of color, and whether the organization is located in a community of color. The only factor for which undergraduates had a higher mean than graduate students was the extent to which they were recruited - the mean was only marginally higher.

There were significant differences between the way males and females rated 11 of the diversity factors. In all these cases, women had higher mean scores than men. Women rated factors related to the gender, race, and class diversity of the organization's staff and leadership; the class, race, and gender diversity of the organization's membership; the presence of diversity programming; and the extent to which the organization reflected the respondent's cultural background significantly higher than men. In other words, these factors were more salient to females than males when considering if they would work in an environmental organization. On the other hand, males were more likely than females to say that the salary offered, opportunities to grow and take on leadership roles, and the opportunities to be promoted were important in their decision to work in an organization. However, these differences in the means were not significant.

The study also examined 11 aggregated diversity factors (see Table 7). The aggregate factors were obtained by combining the scores of related clusters of diversity factors. For instance, four factors related to the organization's location were summed, so were the three factors related to racial diversity. The aggregate factor that was most important to students was leadership/promotion/mentoring opportunities. It scored a mean of 13.52; the maximum score possible was 15 . This aggregate factor was of the greatest significance to Black students. A pattern emerged wherein all 11 aggregate factors were most salient to Black students and least salient to White students.

\section{Salary expectations}

Data from past studies show that environmental leaders often believe that minorities want higher salaries than organizations can afford to pay; hence, the reason they are not hired (Taylor
2007, 2014a, b; Environmental Careers Organization 1992). Respondents were asked to say what is the minimum salary they would accept upon graduation. Though salary is important to the minority students in this study, it is not the most important deciding factor. Minorities are also not anomalous in the way they rank salary and how much they want to be paid for their work. Table 8 shows that $85.7 \%$ of Black students said that the salary offered will be somewhat or very important in their decision to accept a job. In comparison, $80.4 \%$ of White students and $77.3 \%$ of other minority students felt similarly. Table 8 also shows the mean acceptable minimum salary of different groups of respondents. The mean acceptable minimum salary for the sample was $\$ 48,105$. Though students of color had higher minimum acceptable salary expectations than White students, the differences were not significant ( $p=0.123$ ).

Graduate students have significantly higher salary expectations than undergraduates. No graduate student will accept a salary that is less than $\$ 30,000$ annually, but undergraduates indicated would accept a salary as low as $\$ 13,000$ per year. While the mean minimum acceptable salary for undergraduates was $\$ 45,988$, the mean minimum acceptable salary for graduate students was $\$ 52,683(p=0.020)$.

The mean minimum salary expectation of males is higher than that of females; however, the difference is not significant. The mean minimum salary men would accept is $\$ 50,384$. In comparison, the mean minimum salary that women say they would accept is $\$ 47,637$ ( $p=0.576)$.

So, is there a relationship between the environmentalist identity and salary expectations? There seems to be. Students who identify strongly with being an environmentalist have lower salary expectations than those who do not. Hence, students who said they always identified themselves as an environmentalist had the lowest salary expectation $(\bar{x}=\$ 47,179)$ and those who identified as environmentalists sometimes or never had a mean minimum acceptable salary expectation of $\$ 49,305$.

There was no clear pattern between the conservationist identity and salary expectations. The students with the highest salary expectations were those who identified themselves as a conservationist about half the time $(\bar{x}=\$ 49,238)$, while those who identified themselves as conservationists only sometimes had the lowest mean minimum acceptable salary $(\bar{x}=\$ 45,722)$. Similarly, for the environmental justice identity, the students with the highest salary expectations were those who identified themselves as environmental justice practitioners about half the time $(\bar{x}=\$ 54,206)$ and those who identified themselves as environmental justice practitioners only sometimes had the lowest mean minimum acceptable salary $(\bar{x}=\$ 45,821)$. There were also no clear patterns with the scientist identity. The students who say they never identified themselves as a scientist had the highest mean minimum acceptable salary $(\bar{x}=\$ 50,769)$, while those who said they identified themselves as a scientist about half the time who had the lowest mean $(\$ 43,222)$. 
Table 8 Differences in minimum acceptable salary

\begin{tabular}{|c|c|c|c|c|}
\hline Students & $N$ & $\begin{array}{l}\text { Percent feeling that } \\
\text { the salary offer is } \\
\text { somewhat or very } \\
\text { important }\end{array}$ & Range & $\begin{array}{l}\text { Mean minimum } \\
\text { acceptable salary }\end{array}$ \\
\hline Total sample & 149 & 80.6 & $\$ 13,000-\$ 120,000$ & $\$ 48,105$ \\
\hline \multicolumn{5}{|c|}{ Racial or ethnic background: } \\
\hline White & 45 & 80.4 & $\$ 20,000-\$ 90,000$ & $\$ 44,844$ \\
\hline Black & 41 & 85.7 & $\$ 13,000-\$ 120,000$ & $\$ 52,683$ \\
\hline Other minorities & 63 & 77.3 & $\$ 15,000-\$ 90,000$ & $\$ 47,455$ \\
\hline \multicolumn{5}{|l|}{ Student status: } \\
\hline Undergraduates & 111 & 76.1 & $\$ 13,000-\$ 120,000$ & $\$ 45,988$ \\
\hline Graduate Students & 41 & 92.7 & $\$ 30,000-\$ 120,000$ & $\$ 53,683$ \\
\hline \multicolumn{5}{|l|}{ Gender: } \\
\hline Male & 33 & 82.3 & $\$ 15,000-\$ 120,000$ & $\$ 50,384$ \\
\hline Female & 113 & 79.5 & $\$ 13,000-\$ 120,000$ & $\$ 47,637$ \\
\hline
\end{tabular}

\section{Discussion}

The traditional views of minorities often portray them as being stymied and overwhelmed by historical discrimination and marginalization (Foster et al. 2011, 2013; Haynes et al. 2015), spending limited time outdoors, disinterested in the environment, being overly concerned with high wages, lacking knowledge of the environment, and not having the appropriate academic backgrounds to work in environmental organizations (Taylor 2007, 2014a; Environmental Careers Organization 1992; Foster et al. 2011, 2013).

Though such factors are often cited as barriers that hinder minorities from gaining employment in environmental organizations, these are not perceived as barriers for all potential hires. For instance, the Nature Conservancy - one of the largest environmental organizations and one that employs about 4000 people - hired Mark Tercek, an investment banker at Goldman Sachs for 24 years, to be its president and chief executive officer in 2008. At the time of his hiring, Tercek had no formal training in conservation and no prior experience working in environmental organizations. Moreover, Tercek, whose environmental awakening came during a vacation to Costa Rica a few years earlier, admits that nature was not something he paid much attention to till he became a parent and that he spent little time in the outdoors while growing up (Nuwer 2017; Tercek 2017; Jackson 2011; The Economist 2013). However, instead of being penalized for lack of exposure to the outdoors, disinterest in the environment, lack of knowledge of the field, and lack of conservation training, Tercek's banking and investment skills are viewed as highly valued assets, and his lack of environmental experience and interest is framed as an "awakening" to the "call of the wild" (Nuwer 2017). Tercek describes himself as a "late-bloomer to conservation" (Tercek 2017; Jackson 2011).
Data presented above show many of the minority students in the sample to be early-bloomers to conservation, interested in the environment, awakened, and have similar preparation to White students. They are also engaged in campus environmental organizations. Like Tercek, they want to work in the environmental field. Still the question remains: will environmental organizations look past the stereotypes and hire them at greater levels than they have done in the past?

The potential for upward mobility in an organization and the diversity-related institutional infrastructure are key factors that minority students in this study are looking for in environmental organizations when it comes time to decide where they will work. For the most part, minority students are seeking jobs in which they can grow and take on leadership roles, get promotions, and be offered competitive wages.

Are the salary expectations of students of color realistic? Generally speaking, data from the Department of Labor's Bureau of Labor Statistics (BLS) indicate that students' salary expectations discussed above are in the range of what is being paid to environmental workers nationwide. In 2016, the BLS analyzed the wages of 94,600 environmental scientists, 21,000 conservation scientists, and 15,500 foresters. The median annual salary was $\$ 68,910$ for environmental scientists, $\$ 61,810$ for conservation scientists, and $\$ 58,700$ for foresters. Wages were highest in the federal government and lowest in local government jobs. The BLS also studied the wages of 2070 environmental scientists working in social advocacy organizations and found the mean annual salary to be $\$ 63,930$. There are statistics for related professions also. BLS data show that the median pay for agricultural and food scientists is $\$ 62,470$. The mean wage for zoologists and wildlife biologists is $\$ 59,680$; it is $\$ 59,980$ for employees in museums, historical sites, and similar institutions (Bureau of Labor Statistics 2016). 
Furthermore, the BLS data revealed that environmental sector is growing. For instance, the bureau projects that the number of jobs in environmental sciences will increase by $11 \%$ between 2014 and 2024. During that time, the number of jobs in forestry will increase by $8 \%$, and the number of conservation jobs will rise by $7 \%$ (Bureau of Labor Statistics 2016).

Respondents in the sample identified themselves as environmentalists while prizing other professional identities. This phenomenon has been observed in other research. A study of Cornbelt farmers found that they identified themselves as both farmers and environmentalists; i.e., their environmentalist identities overlapped with productivist and naturalist identities (McGuire et al. 2015, 2013).

As the above discussion has shown, the factors that the students identify as most relevant are not the ones that institutional leaders typically think of when asked to identify barriers that prevent minorities from working in environmental organizations. This question was posed to faculty at minorityserving institutions and they also identified lack of leadership opportunities as a critical barrier (Foster et al. 2011, 2013).

This is worth paying attention to as it might be a signal of the new ways in which minorities are looking at jobs in the environmental field. Some emphasis has been placed on minority leadership in the environmental field through programs such as the Environmental Leadership Program founded in 1997 (Grist Staff 2002), and the Minority Environmental Leadership Development Initiative, founded in 2002 (MELDI 2014).

A national diversity report released in 2014 showed a paucity of minorities in top leadership positions in environmental organizations. The finding was similar in the Great Lakes diversity report, also released in 2014 (Taylor 2014a, 2014b). The reports also analyzed interviews with environmental professionals who discussed the lack of leadership and promotion opportunities for minorities in environmental organizations; they also discussed the deleterious impacts that lack of mentoring has had on minority workers (Taylor 2014a). Other factors such as formation of Green 2.0, a group of high-profile people of color professionals campaigning for greater diversity in the environmental field and the appointment of more people of color in leadership positions, may also be influencing students (see https://www.diversegreen.org/about-us/).

Environmental leaders also identify challenges with recruitment as a major barrier (Taylor 2014a; Foster et al. 2013). Most of the students in this study think the extent to which they are recruited will influence their decision to work in the environmental field. Far from lacking interest in environmental careers, this study identifies a pent-up desire from minority students for training and job opportunities in the field. Environmental leaders must rise to the challenge of meeting the needs of minority students by creating greater opportunities to pursue careers in the field. There is still an urgent need for not only internship programs, but leadership training programs as well.

\section{Conclusions}

This study suggests that regardless of race, students in the pipeline expect environmental organizations to be places that engage the issue of diversity seriously. The students indicate that they want to work in environmental organizations but they will also take the state of diversity in those organizations into consideration when they are deciding where to work.

The study also suggests that one-size-fits-all diversity programming might not be the most efficient way to incorporate minorities into the environmental field. Data presented above point to differences between undergraduates and graduate students, males and females, as well as between Blacks and other minorities that are worth taking note of in the development of diversity programs. It would be helpful for environmentalists to acquaint themselves with the nuances of how the various aspects of diversity appeal to different groups and adjust their programming to reach their target audiences more effectively. In short, minorities are not monolithic so it is unlikely that one message will appeal to all of them.

In the broader scheme of things, it would help environmentalists to recruit more effectively if they frame their messages in ways that are more appealing to students. The traditional definitions and images of the environmentalist still appeal to some, but students currently have multiple dimensions to their identities. Hence, a student can simultaneously identify as an environmentalist and an environmental justice practitioner. While the traditional view of the environmentalist separated these two ideologies and approaches, data collected in this study indicate that today's students see these as compatible identities that they adopt simultaneously.

While some types of environmental organizations like federal agencies and environmental nonprofits seem to be places that most students want to work in, this is not the case for all the types of environmental organizations studied. The findings of this study suggest that parks, zoos, aquariums, and museums must work much harder to generate interest among students in general and minorities in particular.

Environmentalists should take advantage of the fact that the environmental field is a growth sector that will be adding jobs in the coming years (Bureau of Labor Statistics 2016). While there might be resistance to diversity-related hiring in organizations because incumbent workers may be fearful that they might lose their jobs to make way for new hires, framing diversity initiatives as part of the overall growth the sector is likely to undergo will ease concerns and garner greater institutional support.

Minority students like the ones participating in this study have much to contribute to the environmental field. Some are in the appropriate training programs, but if they are not recruited and hired, they become part of a leaky pipeline. A porous pipeline hinders diversity efforts as it reduces the likelihood of finding, hiring, and retaining talent. Hiring is only part of the 
story. Environmental organizations should also realize that once hired, these students may not be satisfied with backoffice positions for long, if at all. They seek the professional mobility that comes through open hiring processes, transparent performance reviews and promotions, leadership training, and opportunities to take on leadership roles. They also seek robust and meaningful institutional engagement with diversity issues in their workplaces.

Acknowledgements This project was supported by funds obtained from the Doris Duke Charitable Foundation, the C.S. Mott Foundation, and the Environmental Grantmakers Association.

Open Access This article is distributed under the terms of the Creative Commons Attribution 4.0 International License (http:// creativecommons.org/licenses/by/4.0/), which permits unrestricted use, distribution, and reproduction in any medium, provided you give appropriate credit to the original author(s) and the source, provide a link to the Creative Commons license, and indicate if changes were made.

\section{References}

Adams CE, Moreno M (1998) A comparative study of natural resource professionals in minority and majority groups in the Southeastern United States. Wildl Soc Bull 26:971-981

American Institute of Biological Sciences (2016) Diversity. https://www. aibs.org/diversity/ aibs diversity leadership awards.html. Accessed 11/2016

Beck C, Boersma K, Tysor CS, Middendorf G (2015) Diversity at 100: women and underrepresented minorities in the ESA. Frontiers in Ecology. Available at: https://eswnonline.org/wp-content/uploads/ gravity forms/23-b28d66b6400f67d9648a049f8faf44e0/2015/07/ Beck2014-Diversity-at-ESA.pdf

Bureau of Labor Statistics, U.S. Department of Labor (2016) Occupational outlook handbook, 2016-17 edition. https://www. bls.gov. Accessed 8/2017

Clewell BC, Consentino de Cohen C, Deterding N, Tsui L (2005) Final report on the evaluation of the National Science Foundation Louis Stokes Alliances for Minority Participation Program. Urban Institute, Washington, D.C.

Department of Energy (2017) U.S. energy and employment report. In collaboration with the Department of Labor. Washington, DC: Government Printing Office. Available at: https://energy.gov/ downloads/2017-us-energy-and-employment-report

Doris Duke Charitable Foundation (2016) The Doris Duke conservation scholars program. Available at: https://www.ddcf.org/what-wefund/environment/goals-and-strategies/strengthening-theconservation-field/doris-duke-conservation-scholars-program

Doris Duke Conservation Scholars Program. DDCSP (2016) Doris Duke conservation scholars' program at the University of Michigan. Available at: http://www.ddcsp-umich.com/

Ecological Society of America (2003) Seeds: strategies for ecology education, development and sustainability. The first six years - 1996202. Washington, DC: Ecological Society of America. https://www. esa.org/seeds/pdf/SEEDSreport.pdf. Accessed 11/2016

Environmental Career Organization (1992) Beyond the green: redefining and diversifying the environmental movement. Environmental Careers Organization, Boston

Foster MJ, Bennett C, Sterling EJ, Bynum N (2011) Fostering the development of conservation leadership at minority-serving institutions. Fisheries 36:461-463
Foster NJ, Blair ME, Bennett C, Bynum N, Sterling EJ (2013) Increasing the diversity of U.S. conservation science professionals via the society for conservation biology. Conserv Biol 28:288-291

Grist Staff (2002) Paul Sabin, environmental leadership program. Grist Magazine. Available at: http:/grist.org/article/paul/full/. Accessed 5 May 2016

Haynes N, Jacobson SK, Wald DM (2015) A life-cycle analysis of minority underrepresentation in natural resource fields. Wildl Soc Bull 39:228-238

Holland M, Lawrence D, Morrin D, Hunsaker C, Inouye D, Janetos A, Pulliam HR, Robertson A, Wilson J (1992) Profiles of ecologists: results of a survey of the membership of the Ecological Society of America. The Ecological Society of America, Public Affairs Office, Washington, DC

Jackson N (2011) A conversation with Mark Tercek, CEO the nature conservancy. The Atlantic. December 6. Available at: https://www. theatlantic.com/national/archive/ 2011/12/a-conversation-withmark-tercek-ceo-of-the-nature-conservancy/249442/

Leon, R, Taylor DE (2016) Planting the seeds of inclusion in environmental philanthropy. Stanf Soc Innov Rev. Available at: http://ssir. org/articles/entry/planting_the_seeds_of_inclusion_in environmental_philanthropy

McDonnell JA (2006) Oral history interview with Robert G. Stanton: Director, National Park Service, 1997-2001 (Department of the Interior. Washington, D.C., 2006), p. 7

McGuire J, Morton LW, Cast AD (2013) Reconstructing the good farmer identity: shifts in farmer identities and farm management practices to improve water quality. Agric Hum Values 30:57069

McGuire J, Morton LW, Arbuckle JG, Cast AD (2015) Farmer identities and responses to the social-biophysical environment. J Rural Stud 39:145-155

MELDI. Multicultural Environmental Leadership Development Initiative 2014 The multicultural environmental leadership development initiative. available at: https://meldi.snre.umich.edu. Accessed 03/2014

National Science Foundation (2015) Women, minorities, and persons with disabilities in science and engineering. Arlington: National Center for Science and Engineering Statistics. https://www.nsf. gov/statistics/2015/nsf15311/digest/theme3.cfm\#minbachelors. Accessed 11/2016

New York Times (1990) Earth issues lure a new breed of young worker. July 20. P. 41

NRDC (2014) NRDC announces Rhea Suh as new president. New York: Natural Resources Defense Council. September 17. https://www. nrdc.org/media/2014/140917-0. Accessed 11/2016

Nuwer R (2017) The call of the wild. Delta Sky Magazine (April). Available at: https://deltaskymag.delta.com/Sky-Extras/Favorites/ The-Call-of-the-Wild.aspx

Organization for Tropical Studies (2016) REU (Research Experience for Undergraduates) for U.S. underrepresented minority students summer programs in Costa Rica. https://education.tropicalstudies.org/ en/education/undergraduate-opportunities/programs/reu-researchexperience-for-undergraduates-in-costa-rica.html

Ortega S, Flecker A, Hoffman K, Jablonski L, Johnson-White J, Jurgensen-Armstrong M, Kimmerer R, Poston M, Socha A, Taylor $\mathrm{J}$ (2006) Women and minorities in ecology II (WAMIE II) Committee report. Ecological Society of America, Washington, D.C.

Partnership for Public Service (2007) Best places to work in the federal government. Washington, D.C.: American University, Institute for the Study of Public Policy Implementation, School of Public Affairs. Available at: https://public.tableau.com/profile/partnership.for. public.service\#!/vizhome

Partnership for Public Service (2016) Best places to work in the federal government. Washington, D.C.: American University, Institute for the Study of Public Policy Implementation, School of Public Affairs. Available at: https://public.tableau.com/profile/partnership.for. public.service\#!/vizhome 
Snow D (1992) Inside the conservation movement: meeting the leadership challenge. Island Press, Covelo

Snyder TD, Dillow SA (2015) Digest of educational statistics. Department of Education: National Center for Educational Statistics. https://nces.ed.gov/pubs2015/2015011.pdf. Accessed 11/ 2016

Stanton R (2002) Environmental stewardship for the 21st century: opportunities and actions for improving cultural diversity in conservation organizations and programs. Conservation Council of America, Washington, DC

Stanton R (2005) Cultural diversity in conservation organizations and programs: follow-up survey of progress, initiatives, programs and accomplishments by selected member organizations of the Conservation Council of America, May 2002-May 2004. Washington, D.C.: Conservation Council of America. Available at: https://www.conservationgateway.org/Documents/Stanton-\% 20Post\%20Survey\%20 Follow-up-\%202005.pdf

Taylor DE (1999) Mobilizing for environmental justice in communities of color: an emerging profile of people of color groups. In: Aley J, Burch W, Canover B, Field D (eds) Ecosystem management: adaptive strategies for natural resource organization in the $21^{\text {st }}$ century, Washington, DC, Taylor and Francis, pp 36-67

Taylor DE (2007) Employment preferences and salary expectations of students in science and engineering. Bioscience 57:175-185

Taylor DE (2008) Diversity and the environment: myth-making and the status of minorities in the field. Res Soc Probl Public Policy 15:89-148

Taylor DE (2014a) The state of diversity in environmental organizations: mainstream NGOs, foundations, and government agencies (Ann
Arbor, University of Michigan). https://www.diversegreen.org/thechallenge/

Taylor DE (2014b) Environmental organizations in the Great Lakes region: an assessment of institutional diversity. University of Michigan School of Natural Resources and Environment, Ann Arbor

Taylor DE (2015) Gender and racial diversity in environmental organizations: uneven accomplishments and cause for concern. Environmental Justice 8:165-180

Tercek M (2017) Biography. The nature conservancy. Available at: https:/www.nature.org/about-us/governance/executive-team/marktercek-biography.xml

The Bulletin of the Ecological Society of America (1993) Business manager's report. 74(4):301. Available at: https://onlinelibrary.wiley. com/doi/10.2307/20167778/pdf

The Economist (2013) Nature's banker: lessons from the nature conservancy. Available at: https://www.economist.com/news/businessbooks-quarterly/21581710-lessons-nature-conservancy-naturesbanker1710. Accessed 07/2017

U.S. Census Bureau (2016) Quick facts: United States. Washington, DC: Department of Commerce. Available at: https://www.census.gov/ quickfacts/fact/table/US/PST045216

Valtlin T (2015) Aaron Mair elected Sierra Club president. https://www. sierraclub.org/planet/ 2015/05/aaron-mair-elected-sierra-clubpresident. Accessed 11/2016

Wildlife Conservation Society (2015) Bridging the gap. New York: Wildlife Conservation Society. https://www.wcs.org/educators/ educational-research-and-evaluation/bridging-the-gap. Accessed $11 / 2016$ 